\title{
Ph.d.-vejledning i et akademisk, markedsdrevet og samfundsforandrende perspektiv
}

Pia Bøgelund, ph.d., ekstern lektor, Institut for Planlægning, Aalborg Universitet.

Anette Kolmos, ph.d., professor, Institut for Planlægning, Aalborg Universitet.

\section{Reviewet artikel}

Denne artikel identificerer og analyserer 3 idealtypiske ph.d.-vejledningsperspektiver, der korresponderer med forskellige forståelser af videnskabssyn og akademiske værdisæt. De 3 vejledningsperspektiver bygger på en interviewundersøgelse blandt 12 erfarne vejledere ved Det Teknisk-Naturvidenskabelige Fakultet på Aalborg Universitet. De identificeres på baggrund af vidensskabssyn og empirisk analyse, og udgør 1) et klassisk akademisk perspektiv; 2) et nyt management perspektiv, der i højere grad vægter projektledelse og produktivitet samt 3) et samfundsforandrende perspektiv baseret på uddannelse af forandringsagenter og 'empowerment' af den ph.d.-studerende. Artiklen konkluderer, at ph.d.-vejlederes videnskabssyn og akademiske værdisæt sætter rammerne for udfoldelsen af vejlederrollen og valg af værktøjer, og som sådan bør ph.d.-vejledere eksplicit stifte bekendtskab med og diskutere disse væsensforskellige perspektiver på vidensproduktion.

\section{Aktuelle udviklingstendenser på ph.d.-vejledningsområdet - arbejdskontekst og forskning}

Ph.d.-vejledningsområdet er under forandring i disse år. Den enkelte vejleder uddanner flere ph.d.ere end tidligere samtidig med, at flere af dem har en international baggrund. Finansieringen af ph.d.-projekterne bliver stadig mere forskelligartet, hvor ph.d.-studerende kan være fuldt ud finansieret af universitetet, helt eller delvist finansieret af erhvervslivet eller finansieret af (udenlandske) stipendier og egne midler. Ledelsesmæssigt, kollegialt og karrieremæssigt er der større forventninger til de ph.d.-studerende - og dermed også til deres vejledere - om at færdiggøre studiet til tiden og i højere grad bidrage til den videnskabelige produktion (Forsknings- og innovationsstyrelsen, 2011). Alt i alt stiller forandringerne nye arbejdsmæssige udfordringer op for ph.d.-vejlederne.

En aktuel interviewundersøgelse blandt 12 ph.d.-vejledere analyserer, hvordan ph.d.-vejledere reagerer på de nye arbejdsmæssige udfordringer - hvordan deres selvforståelse som vejledere påvirkes, og hvordan deres praksis forandres (Bøgelund 
\& Kolmos, 2013). Undersøgelsen identificerer forskellige tilgange til at håndtere forandringerne. Kendetegnende for tilgangene er, at de stemmer overens med vejledernes generelle forståelse af formålet med at uddanne ph.d.-studerende. For nogle vejledere bliver denne forståelse udfordret af de nye arbejdsmæssige udfordringer, for andres vedkommende bliver den understøttet af de forandringer, der sker på ph.d.området og i universitetsregi mere generelt. Det er disse tilgange, vi i det følgende vil kvalificere til egentlige idealtypiske perspektiver.

Løbende - under de aktuelle forandringer på ph.d.-vejledningsområdet - er der kommet flere håndbøger omkring ph.d.-vejledning adresseret til både vejledere og studerende. Specielt i UK er der udkommet en del litteratur, som fokuserer på, hvordan de ph.d-studerende bedst håndterer forskningsprocessen, herunder også vejlederens betydning for denne (Rugg \& Petre, 2004; Elley \& Jennings, 2005; Delamont, Atkinson \& Parry, 2004; Dunleavy, 2003). Karakteristisk for disse og lignende bøger er, at der er fokus på funktioner og værktøjer uden, at der nuanceres særligt mellem forskellige vejledningstilgange. Det gør derimod Handal \& Lauvås (2006), Grant (2005), Dysthe (2002) og Lee (2008). De beskæftiger sig alle mere konceptuelt med ph.d.-vejledningens formål og indhold og bevæger sig dermed ud over et egentligt værkstøjsniveau. Ingen af dem beskæftiger sig dog direkte med betydningen af vejlederes arbejdsmæssige udfordringer, også kaldet den arbejdsmæssige kontekst, eller vejlederes generelle forståelse af formålet med at uddanne ph.d.-studerende, også kaldet deres syn på vidensproduktion. Det er intentionen i det følgende.

I denne artikel undersøger vi således på hvilken måde, forskellige forståelser af videnskabssyn og værdisæt præger ph.d.-vejledningen. Ph.d.-vejledningen her forstået som vejlederes selvforståelse og praksis. Vi vil dermed sætte fokus på vejlederens arbejdsmæssige kontekst og syn på vidensproduktion i en verden, hvor også andre hensyn end vejledningshensyn spiller ind på ph.d.-vejledningen. Konkret analyserer og begrebsliggør vi ph.d.-vejledning på baggrund af en teoretisk ramme og en ny analyse af interviewene fra den omtalte interviewundersøgelse.

\section{Vidensproduktion i et universitetskulturelt og historisk perspektiv}

Som tidligere nævnt viser Bøgelund \& Kolmos (2013), at vejlederes tilgang til de nye udfordringer stemmer overens med deres generelle forståelse af formålet med at uddanne ph.d.-studerende. Forståelse af universitetets funktion og værdigrundlag er således en afgørende faktor i den praksis, som ph.d.-vejledere udøver, og teorier omkring vidensproduktion på de danske universiteter og den historiske udvikling af universitetet bliver relevante.

Universitetets raison d'etre er vidensproduktion og uddannelse af kandidater, der behersker viden, kompetencer og færdigheder. Uddannelsen af ph.d.-studerende er et centralt element i denne sammenhæng, og hvordan, den enkelte vejleder opfatter 
formålet med uddannelsen af ph.d.-studerende, vil naturligvis påvirke den enkelte vejledningsproces. Inspireret af Wenneberg (2001), Barnett (1994; 2011) og Jamison et al. (2011) er det muligt at identificere 3 forskellige perspektiver på vidensproduktion ud fra en historisk og uddannelsessociologisk synsvinkel: Et akademisk, et markedsorienteret og et samfundsforandrende ${ }^{1}$ ( se tabel 1).

Tabel 1.3 perspektiver på vidensproduktion

\begin{tabular}{|c|c|c|c|}
\hline Tabel 1 & $\begin{array}{l}\text { Vidensproduktion i et } \\
\text { akademisk perspektiv }\end{array}$ & $\begin{array}{l}\text { Vidensproduktion i et } \\
\text { markedsperspektiv }\end{array}$ & $\begin{array}{l}\text { Vidensproduktion i et } \\
\text { samfundsforandrende } \\
\text { perspektiv }\end{array}$ \\
\hline $\begin{array}{l}\text { Universitetets } \\
\text { formål }\end{array}$ & $\begin{array}{l}\text { At producere sand viden } \\
\text { og uddanne kandidater } \\
\text { der har tilegnet sig den- } \\
\text { ne viden }\end{array}$ & $\begin{array}{l}\text { At producere tillidsvæk- } \\
\text { kende og brugbar viden }\end{array}$ & $\begin{array}{l}\text { At producere tillidsvæk- } \\
\text { kende og brugbar viden i } \\
\text { en globaliseret verden }\end{array}$ \\
\hline Vidensbegreb & $\begin{array}{l}\text { Viden som sand, begrun- } \\
\text { det overbevisning } \\
\text { Vidensproduktion er det } \\
\text { interessante }\end{array}$ & $\begin{array}{l}\text { Viden som social størrelse } \\
\text { Anvendelse af viden er } \\
\text { det interessante }\end{array}$ & $\begin{array}{l}\text { Viden som kilde til em- } \\
\text { powerment og forandring } \\
\text { Værdibaseret, kontekstuel } \\
\text { vidensudveksling er det } \\
\text { interessante }\end{array}$ \\
\hline $\begin{array}{l}\text { Universitetet } \\
\text { i samfundet }\end{array}$ & $\begin{array}{l}\text { Universitetet skal pro- } \\
\text { ducere sand viden og } \\
\text { øge vidensbanken i sam- } \\
\text { fundet }\end{array}$ & $\begin{array}{l}\text { Universitetet skal med- } \\
\text { virke til at skabe økono- } \\
\text { misk vækst og velfærd }\end{array}$ & $\begin{array}{l}\text { Universitetet skal medvir- } \\
\text { ke til change agency i en } \\
\text { verden med globale ud- } \\
\text { fordringer }\end{array}$ \\
\hline
\end{tabular}

Det klassiske syn på universiteternes rolle i samfundet - det akademiske - er, at de skal producere sand viden og uddanne kandidater, der har tilegnet sig denne viden (Wenneberg, 2001). At producere sand viden er et mål i sig selv. Det er faglighed for faglighedens skyld med fokus på faglige normer og værdier. Hvordan denne viden bringes i anvendelse, og af hvem, er ikke det primære i dette perspektiv, tværtimod er viden og læring præget af teoretiske problemstillinger og traditionelle akademiske dyder (Barnett, 2011). Alle universiteter grundlagt tidligere end midten af det forrige århundrede må siges at være 'født' med dette udgangspunkt.

Omkring midten af 1900-tallet begynder en ny forståelse af videnskab og teknologi at vokse frem, som efterhånden får betydning for universiteternes vidensproduktion (Jamison et al., 2011, s. 13ff). Baggrunden for denne nye forståelse er at finde i det øgede samfundsmæssige behov for innovation, og at kandidater fra universitetet er $\mathrm{i}$ stand til at anvende deres viden gennem tilegnelse af færdigheder og kompetencer ikke mindst gennem etablering af egne virksomheder (Barnett, 1994). Den nye forståelse - vidensproduktion i et markedsperspektiv - er centreret omkring det kommercielle, det entreprenørmæssige og innovative - at tjene penge og gøre forretning.

\footnotetext{
${ }^{1}$ De to første perspektiver er taget fra Wenneberg (2001), mens det sidste perspektiv er blevet til med inspiration fra Barnett (1994) og Jamison et al. (2011).
} 
Ideer og opfindelser bliver til udvikling af nye produkter, der i sidste ende bliver til profit. Nytten af den viden, der produceres, og det dialektiske forhold mellem anvendelse og vidensproduktion kommer mere og mere i spil på universiteterne (Jamison et al., 2011, s. 14; Wenneberg, 2001, s. 40ff).

Sideløbende hermed sker der en forandring i forståelsen af, hvad viden er, og hvor viden produceres. Vidensbegrebet bliver bredere og kan produceres i kollaboration mellem universiteter og virksomheder. Derved får viden et mere socialkonstruktivistisk udgangspunkt: Viden er ikke længere sand per se, men en social størrelse der kan være produceret under mere eller mindre tillidsvækkende former (Wenneberg, 2001, s. 41). Universiteternes rolle transformeres fra at være en institution for selvrefererende vidensproduktion til at blive én aktør blandt flere, der skal medvirke til at fremme vækst og velstand. I denne periode ændres også ledelsen af universiteterne til 'New Management', hvor ledere i højere grad er ansatte og med større magtbeføjelser, og hvor den statslige regulering af universiteterne bliver gennemsyret af en produktionstankegang (Barnett, 2011). Nye samarbejdsflader i form af forskerparker, fælles forskningsprojekter mellem virksomheder og universitet, universitetsforskere, der fungerer som konsulenter osv., kan ses som eksponenter for dette perspektiv.

Det 3. perspektiv - vidensproduktion i et samfundsforandrende perspektiv - har sine rødder i de sociale, folkelige bevægelser, der fra tid til anden har sat en dagsorden i den vestlige verden i forhold til basale problemstillinger i livet (Jamison et al., 2011, s. 22ff). Det har fx været de fredsbevarende, kvindefrigørende og miljøforkæmpende bevægelser fra 60'erne og fremefter, der har forsøgt at forholde sig til og samarbejde om væsentlige demokratiske, miljømæssige eller ligestillingsrelaterede udfordringer på verdensplan. Udvikling og udveksling af viden på tværs af discipliner og kulturer er et kendetegn for vidensproduktion i dette perspektiv. Det primære er, at den viden, der produceres og anvendes, bringer reelle forandringer og forbedringer med sig, som retter sig mod øget lighed, netværk, demokrati og frigørelse (Barnett, 1994). Det er et involverende og stillingstagende perspektiv med fokus på integritet, identitetsudvikling og personlighedsmodning som del af den faglige diskurs.

De 3 perspektiver rummer forskellige videnskabssyn: Hvordan ny viden opstår, hvad der er vigtigt at lægge mærke til mht. videnskab og teknologi og hvilken rolle viden, videnskab (og teknologi) kan eller skal spille i samfundet. De to første perspektiver - vidensproduktion i et akademisk og i et markedsperspektiv - beskrives af Jamison et al. (2011) som langt mere dominerende diskurser i samfundet end det sidste. På universiteterne har det akademiske perspektiv traditionelt domineret men er til stadighed under pres fra statslig regulering med ønsket om flere produkter målt i bl.a. kandidater og artikler og arbejdslivets ønske om en større arbejdslivs- og praksisorientering for både kandidater og forskningen. Jamison et al.s pointe er, at 
det klassiske akademiske perspektiv ofte tager rollen som en slags trængt reaktionær protest, hvorimod det samfundsforandrende perspektiv mere tager rollen som en kreativ overskridende protest.

I det følgende relateres de 3 perspektiver til den føromtalte empiriske interviewundersøgelse.

\section{Metodiske og analytiske overvejelser}

Artiklens empiriske materiale udspringer, som nævnt, af en interviewundersøgelse blandt 12 ph.d.-vejledere med det formål at undersøge, hvordan flere ph.d.-studerende og mere internationale ph.d.-studerende ${ }^{2}$ påvirker vejledernes selvforståelse og praksis. ${ }^{3}$ Vejlederne er udvalgt på to forskerskoleprogrammer på Det TekniskNaturvidenskabelige Fakultet på Aalborg Universitet. Der er udvalgt 6 erfarne vejledere på hvert program. De er udvalgt på baggrund af stor vejledererfaring og for at sikre spredning i sektionsmæssig tilhørsforhold, gerne med en nøglerolle i forhold til at rekruttere ph.d.-studerende i det pågældende faglige miljø. Alle vejledere har erfaring med internationale ph.d.-studerende, og de har eller har haft mange ph.d.studerende. ${ }^{4}$ Det ene forskerskoleprogram ligger i grænsefladen mellem teknologiske og samfundsfaglige fagtraditioner, mens det andet forskerskoleprogram er kendetegnet ved klassiske, tekniske discipliner. ${ }^{5}$ En anden forskel på de 2 programmer er, at det første program først for nylig har været igennem en omstillingsproces til mange og fortrinsvis internationale ph.d.-studerende, mens det andet program gennemgik denne transformation for ca. 10 år siden. Interviewene tog mellem 1-1/1/2 time, og vejlederne blev udspurgt - efter en semistruktureret interviewguide, hvor analyserammen var ridset op - om deres selvforståelse som vejledere, deres konkrete praksis, deres forventninger til de ph.d.-studerende, i forhold til den arbejdsmæssige kontekst, herunder deres generelle erfaringer med internationale ph.d.-studerende, og det at have flere end 2-3 ph.d.-studerende på en gang.

En første induktiv analyse af det empiriske materiale, hvor vejledernes udsagn blev analyseret $\mathrm{i}$ forhold til analyserammen, identificerede 3 væsensforskellige vejledningstilgange til de nye udfordringer. Vi kunne hermed se konturerne til nogle forskellige typologier med forskellige værdisæt og forskellige vejledningspraksisser, hvilket gav anledning til en afsøgning af relevante teoretiske perspektiver. Resulta-

\footnotetext{
${ }^{2}$ Mere internationale ph.d.-studerende betyder, at en større andel af de ph.d.-studerende har en international baggrund.

${ }^{3}$ Et projekt finansieret i et samarbejde mellem Aalborg Universitet og SCKK med titlen Kompetenceløft af ph.d.-vejlederen i en interkulturel virkelighed (Bøgelund, 2011).

${ }^{4}$ Hovedvejlederfunktion for (gennemsnitligt) mere end 12 ph.d.-studerende. En enkelt har haft 72, og han er ikke talt med i dette gennemsnit.

${ }^{5}$ For en nærmere beskrivelse af udvælgelse, interviewguide og efterfølgende analyse se Bøgelund \& Kolmos (2013).
} 
terne af denne afsøgning er gengivet i afsnittet ovenfor. I den følgende analyse af det empiriske materiale er udsagn fra hver enkelt vejleder gennemgået ift. den teoretiske forståelsesramme - de 3 perspektiver på videnskabsproduktion. Vi har således valgt at genanalysere empirien ud fra en begrebsmæssig vinkel, hvorved empirien bliver anvendt til at berige og illustrere de tre typologier.

Resultaterne af analysen kan gengives ved en inddeling af vejledernes udsagn i forhold til deres mere eller mindre bevidste syn på vidensproduktion og tilhørende praksis som vejledere. Dette er illustreret i tabel 2 og 3 . Den teoretiske opdeling i de 3 perspektiver på vidensproduktion har været styrende for fordelingen af udsagn. Vejledernes egne ord er så vidt muligt anvendt og angivet med kursiv. Perspektiverne er idealtyper, således som de er præsenteret her, med henblik på at tydeliggøre de 3 perspektiver. De fleste vejledere har udsagn, der kan relateres til alle 3 perspektiver. Ingen af vejlederne passer altså entydigt ind i det ene eller det andet perspektiv. Ligeledes er det vigtigt at understrege, at alle vejlederes udsagn har kunnet relateres til mindst et af de 3 perspektiver.

\section{Vejlederes syn på vidensproduktion}

Tabel 2 viser, hvad der er væsentligt og i fokus for det enkelte vejledningsperspektiv. Den viser også, hvad der ikke tillægges værdi eller er direkte uønsket.

Tabel 2. Idealtypisk selvforståelse som ph.d.-vejleder

\begin{tabular}{|c|c|c|c|}
\hline Tabel 2 & $\begin{array}{l}\text { Vidensproduktion i et } \\
\text { akademisk perspektiv }\end{array}$ & $\begin{array}{l}\text { Vidensproduktion i et } \\
\text { markedsperspektiv }\end{array}$ & $\begin{array}{l}\text { Vidensproduktion i et sam- } \\
\text { fundsforandrende perspek- } \\
\text { tiv }\end{array}$ \\
\hline $\begin{array}{l}\text { Hvad er } \\
\text { vigtigt/ } \\
\text { positivt } \\
\text { værdiladet i } \\
\text { det enkelte } \\
\text { perspektiv? }\end{array}$ & $\begin{array}{l}\text { Gode diskussioner og } \\
\text { godt samarbejde } \\
\text { Faglig prestige i at være } \\
\text { ph.d.-vejleder } \\
\text { Sætte sit præg på nogen og } \\
\text { bruge de bedste i eget } \\
\text { system } \\
\text { Bidrage akademisk til et felt } \\
\text { og gøre en engageret } \\
\text { forskel } \\
\text { Faglig passion for fagets } \\
\text { skyld }\end{array}$ & $\begin{array}{l}\text { Samarbejde med indu- } \\
\text { strien om reelle problemer } \\
\text { Bidrage til lokal/national } \\
\text { vakst og velfxrd } \\
\text { Ressourceoptimering: Pro- } \\
\text { ducere mange ph.d.ere, } \\
\text { artikler og patenter } \\
\text { Holde sig opdateret og } \\
\text { understøtte egen forsk- } \\
\text { ning vha. unge menne- } \\
\text { sker } \\
\text { Bruge ph.d.-vejledning } \\
\text { som boosting af CV }\end{array}$ & $\begin{array}{l}\text { Skabe en positiv forandring i } \\
\text { hjemlandet - globalt perspek- } \\
\text { tiv } \\
\text { Læring initieret for de stude- } \\
\text { rendes egen skyld } \\
\text { Uddannelse af fuldgyldige } \\
\text { akademikere - kritiske og selvkø- } \\
\text { rende } \\
\text { Forpligtelsen over for andre } \\
\text { lande ift. at sprede pbl, demo- } \\
\text { krati og humanistiske idealer } \\
\text { Den pædagogiske udfordring } \\
\text { ved at få folk igennem }\end{array}$ \\
\hline
\end{tabular}


Argumenter begrundet i status

Uselvstændige og umotiverede studerende

Hvad er uinteressant /negativt værdiladet $\mathrm{i}$ det enkelte perspektiv?

Deliverables på bekostning af teoretisk og metodologisk substans

Produktivitetshensyn der styrer ph.d.-uddannelsen

Projektledelse
Kulturtilvænning og nursing af den enkelte ph.d.

Prioritering af den akademiske udfordring

Studerende uden referencer og

Uddannelse af de tungeste vi har uden at få ressourcer

Snævert fokus på uniøkonomi og hjerneflugt ud af landet

For stor andel af udlændinge
Et snævert fokus på hvor lang tid det tager at uddanne ph.d.-studerende

At køre tingene som om det var et samlebånd på en fabrik

Anvendelsen af ph.d.studerende som primært arbejdskraft $i$ vejlederens projekter

At betragte ph.d.-studerende som research assistents

Nedenfor er de tre perspektiver yderligere illustreret gennem tre citater fra 3 vejledere, der er inspireret af hhv. det akademiske, det markedsorienterede og det samfundsforandrende perspektiv. Citaterne viser det, der står i centrum for hvert enkelt perspektiv ift. at vejlede ph.d.-studerende: Den faglige passion, nytten af den ph.d.studerende og ønsket om en kulturrevolution ${ }^{6}$ :

"Jeg nyder virkelig ph.d.-processen og miljøet omkring den rigtig meget. Jeg synes, at det er spændende at arbejde med folk, der går gennem sådanne opdagelsesprocesser. ... Især det med at opbygge et kritisk perspektiv sætter jeg stor pris på. ... at se nogen udvikle sig til en akademiker. ... at de føler sig inspirerede, og synes det er spændende. ... Det er ikke nok, at de bare passerer gennem systemet ... Hvis deres passion ikke er der, hvorfor er vi her så? ... [E]n af belønningerne for [at vejlede] er at dele den[ passion]." (Akademisk orienteret vejleder).

"Jeg kan godt lide, at problemstillingerne kommer fra industrien, fordi det er reelle problemer... Folk $i$ industrien har typisk ikke tid til at gå $i$ dybden med noget ... og så er det rart at have de her ph.d.-studerende. ... Nu snakker jeg med en virksomhedshat. ... Universitetet fär [funding og realitet ud af det.] ... [De ph.d.-studerende] er nogle dygtige ressourcer ... det [er] en meget bedre investering, at jeg bruger noget af min tid på en ung, dygtig person og fär vedkommende til at lave det, som jeg ellers skulle have lavet." (Markedsorienteret vejleder).

${ }^{6}$ I det omfang citaterne oprindeligt har været på engelsk, er de blevet oversat til dansk. Ligeledes er citaterne rettet til, så sproget bliver flydende. Selvsagt uden at den oprindelige mening er gået tabt. 
"Hvis jeg fär en dansk ph.d.-studerende, vil jeg på ethvert tidspunkt tage imod med kyshånd, men jeg mener også, at vi har en forpligtelse over for de andre lande... Man skal $i$ bund og grund holde fast $i$, at ... $i$ de 3-4 år man er her [som international ph.d.-studerende], kan man lære en masse. ... Målet er ikke bare at lave forskere, det er også at lave folk der kan være innovative i deres systemer ... Det er en kulturrevolution vi er med til at lave, når vi fär dem til at opfore sig lidt mere demokratiske, lidt mere fordomsfrie, lidt mere danske. Det synes jeg er vigtigt at fastholde." (Samfundsforandrende vejleder).

Udsagnene i tabellen og de tre citater viser kernen i det enkelte perspektiv på vidensproduktion i universitetsregi. Den enkelte vejleder kan som nævnt have flere facetter, hvilket også gælder de 3 ovenfor citerede vejledere. Det er i højere grad mikset hos den enkelte vejleder - og på tværs af vejledere - der er interessant. I tråd med Jamison et al.s (2011) pointe er det markedsperspektivet, der fylder mest blandt de 12 interviewede vejledere, og det samfundsforandrende perspektiv, der fylder mindst. Alle vejledere har det akademiske perspektiv, om end der er store indbyrdes forskelle, og betydningen i nogle tilfælde er meget lille. Det er også værd at bemærke, at de vejledere, der bekender sig mest til det akademiske perspektiv og det samfundsforandrende perspektiv, passer fint ind i Jamison et al.s (2011) pointe om, hvordan de respektive forholder sig til det dominerende markedsperspektiv - reaktivt eller mere proaktivt.

Der er en mærkbar forskel på de to grupper af vejledere, når man kigger på vejlederne programvis. Pluralismen er større på det forskningsskoleprogram, der bevæger sig på grænsefladen mellem teknologiske og samfundsfaglige fagtraditioner, mens markedsperspektivet er klart dominerende på det andet program. Kigger man på de enkelte forskningsgrupper, der er tilknyttet de to programmer, er det endvidere muligt at identificere hele miljøer, der primært er domineret af et bestemt perspektiv eller af en bestemt kombination af perspektiver. Kombinationen af de forskellige perspektiver hos den enkelte vejleder kan i øvrigt se ud på mange måder. Selv om der kan være modstridende logikker i markedsperspektivet og det samfundsforandrende perspektiv, er der eksempler på vejledere, der lader sig inspirere af begge perspektiver. Typisk med en overvægt til det ene af perspektiverne. Perspektiverne er ikke gensidigt udelukkende, selv om det kan give anledning til interne afvejningsproblematikker.

\section{Vejlederes praksis i lyset af deres syn på vidensproduktion}

Som det fremgår af tabel 3, får den enkelte vejleders syn på vidensproduktion stor betydning for, hvordan han eller hun går til opgaven som vejleder. Det er ikke uden betydning, hvordan man orienterer sig i forhold til de forskellige videnskabssyn. Det har betydning for tilgang, tidsanvendelse og tiltro til den enkelte ph.d.-studerende. I 
tabellen er tilføjet eksempler på konkrete aktiviteter. De er ikke særegne for det enkelte perspektiv. Samme aktivitet kan udfolde sig inden for alle 3 perspektiver, men vil være tillagt forskellig værdi og betydning.

Tabel 3. Idealtypisk praksis som ph.d.-vejleder

\begin{tabular}{|c|c|c|c|}
\hline Tabel 3 & $\begin{array}{l}\text { Vidensproduktion i et } \\
\text { akademisk perspektiv }\end{array}$ & $\begin{array}{l}\text { Vidensproduktion i et } \\
\text { markedsperspektiv }\end{array}$ & $\begin{array}{l}\text { Vidensproduktion i et } \\
\text { samfundsforandrende } \\
\text { perspektiv }\end{array}$ \\
\hline Mødested & $\begin{array}{l}\text { Det professionelle, } \\
\text { faglige univers }\end{array}$ & $\begin{array}{l}\text { Det virksomhedsrettede, } \\
\text { faglige univers }\end{array}$ & $\begin{array}{l}\text { Det faglige, sociale og } \\
\text { kulturelle univers }\end{array}$ \\
\hline Forventning & $\begin{array}{l}\text { Kvalitet, højt niveau og } \\
\text { selvstændighed }\end{array}$ & $\begin{array}{l}\text { Kvalitet, selvstændighed, } \\
\text { drive og evne til at passe } \\
\text { ind }\end{array}$ & $\begin{array}{l}\text { At blive færdig er pri- } \\
\text { mært et spørgsmål om } \\
\text { den rette støtte }\end{array}$ \\
\hline Fokus & $\begin{array}{l}\text { Motivation og faglig } \\
\text { guidance ift. potentiale }\end{array}$ & $\begin{array}{l}\text { Produktion af brugbare } \\
\text { resultater }\end{array}$ & $\begin{array}{l}\text { Forstå, reflektere og an- } \\
\text { vende teori og få det } \\
\text { omsat til ny praksis i ny } \\
\text { kontekst }\end{array}$ \\
\hline Rolle & Faglig sparringspartner & Projektleder & All round facilitator \\
\hline $\begin{array}{l}\text { Eksempler på } \\
\text { aktiviteter }\end{array}$ & 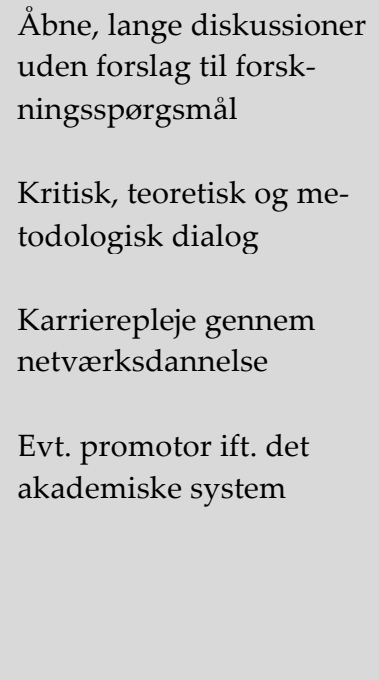 & $\begin{array}{l}\text { Aktivt styrende - ofte del } \\
\text { af differentieret vejleder- } \\
\text { system med } 2 \text { vejledere } \\
\text { Rekruttering ift. kvalitet, } \\
\text { attitude og kulturtilvæn- } \\
\text { ning } \\
\text { Personalehåndtering - } \\
\text { bl.a. ift. dygtighed og } \\
\text { tilpasning } \\
\text { Etablering af selvkørende } \\
\text { fagligt fællesskab og } \\
\text { mentorordning }\end{array}$ & $\begin{array}{l}\text { Aktivt faciliterende og ti } \\
\text { stede i starten. Praksis- } \\
\text { øvelser og rammer - ofte } \\
\text { flere vejledere } \\
\text { Skabe et godt socialt og } \\
\text { fagligt miljø omkring de } \\
\text { studerende } \\
\text { Anvendelse af humor og } \\
\text { formidling af dansk kul- } \\
\text { tur } \\
\text { Globale aktiviteter i form } \\
\text { af kulturrejser og work- } \\
\text { shops }\end{array}$ \\
\hline
\end{tabular}

I det akademiske perspektiv er der ofte tale om et gensidigt professionelt forhold, hvor vejledermøder bruges til at diskutere faglige begreber og udfordringer. Det er en typisk praksis i dette perspektiv, at udenomsfaglige forhold ikke findes i vejlederrelationen. I det omfang sociale eller kulturelle forhold bliver berørt, sker det ofte uden for det enkelte vejledermøde, i forbindelse med kaffepauser eller ved transport til og fra konferencer. Og mere på det kuriøse plan end som del af vejledningsindsatsen. Der er i dette perspektiv også generelt en høj forventning til den ph.d.-studerendes engagement og selvstændighed. Passion og faglig kritisk sans sættes særligt højt. Vejlederen kan se det som en del af sin opgave at introducere den unge ph.d.studerende til sit eget netværk og guide den unge i retning af fagligt interessante forskningsmiljøer og konferencer. 
En vejleder, der tager sit udgangspunkt i markedsperspektivet, vil primært opfatte sig selv som projektleder, og relationen til den ph.d.-studerende kan have visse lighedspunkter med relationen mellem en arbejdsgiver og en medarbejder. Det er vejlederen, der lægger rammerne for projektet og tager styringen i starten. Den ph.d.studerende er en arbejdsressource, der forventes at bidrage med egen kreativitet og idérigdom inden for de givne rammer. Derfor er udvælgelsen, og den løbende personalehåndtering og -pleje, også af stor vigtighed. Ofte er flere ph.d.-studerende koblet til det samme projekt eller område, og bestræbelserne går i retning af at indfri virksomhedsmæssige krav og akademiske mål i et nærmere givet forhold. Vejlederen vil typisk også være optaget af at få den akademiske og virksomhedsrettede produktivitet tilrettelagt så effektivt som muligt. Det kan fx gøres ved at fordele vejlederopgaven mellem flere vejledere, der har forskellige kompetencer. Etablering af mentorordninger, hvor postdocs fungerer som støtte for nytilkomne ph.d.-studerende eller etablering af fagmiljøer med udstrakt grad af sparring og 'samskrivning', kan også være en del af vejlederens praksis.

En vejleder, med rod i det samfundsforandrende perspektiv, opfatter i høj grad den ph.d.-studerendes refleksive dannelse og evne til mestring og change agency som en del af vejlederopgaven. Derfor har denne vejledertype en langt bredere faglig, kulturel og social interesse i den ph.d.-studerendes udvikling end de to andre, og vejleder det hele menneske inklusiv dannelse og identitet. Et aspekt der i særlig grad kommer i spil i forhold til internationale ph.d.-studerende, der er fremmede over for den pædagogiske og demokratiske praksis, som de danske universiteter, herunder ikke mindst Aalborg Universitet, står for. Som det tidligere citat viser, har disse vejledere den opfattelse, at de skal medvirke til at uddanne refleksive og innovative ph.d.studerende, der kan gøre en forskel i deres eget hjemland. Aktiviteter, der kan støtte op omkring dette mål, er etablering af et stærkt fagligt og socialt fællesskab; introduktion til danske værdier, fremgangsmåder og dansk sprog; udstrakt brug af praksisøvelser, strukturering og forventningsafstemning samt høj grad af tilgængelighed. I en lidt større sammenhæng giver kulturrejser, workshops og samarbejdsprojekter på globalt plan værdifuld kulturindsigt og samarbejdspartnere.

\section{Konklusion}

Denne artikel beskæftiger sig med vejlederens arbejdsmæssige kontekst og syn på vidensproduktion og er som sådan meget kontekstbunden. Den bygger på udsagn fra 12 analytisk udvalgte ph.d.-vejledere på 2 ligeledes analytisk udvalgte ph.d.programmer på Det Teknisk-Naturvidenskabelige Fakultet på Aalborg Universitet. Validiteten af resultaterne er således høj for netop denne type kontekst - det teknisknaturvidenskabelige område i en nordeuropæisk sammenhæng. Hvor valide resultaterne er i fx samfundsfaglige/humanistiske forskningsmiljøer eller i universitetsmiljøer, der institutionelt set er meget anderledes sat sammen, må bero på en nærmere undersøgelse. Med dette in mente skal artiklen opsummeres som følger. 
De 3 opstillede perspektiver på vidensproduktion i universitetsregi, og den mere uddybende identifikation og analyse af 3 korresponderende vejledningsperspektiver, leder frem til idealtyper, hvor der er væsensforskellige formål med og aspekter ved at uddanne ph.d.-studerende. Det er som sådan ikke ligegyldigt for ph.d.-vejledningen, hvilket perspektiv den enkelte ph.d.-vejleder lader sig inspirere af. Der er forskel på, om formålet med at uddanne ph.d.-studerende er at forfine og opkvalificere den faglige passion, at nyttiggøre en dygtig ressource eller at uddanne folk, der kan være innovative i deres egne systemer på værdibaseret grundlag.

Det forskerskoleprogram, der har størst tradition for konkret samarbejde med det private erhvervsliv, og i øvrigt har længst erfaring med at håndtere mange, internationale ph.d.-studerende, er også det forskerskoleprogram, hvor det markedsdrevne perspektiv står stærkest. Selv på det andet forskerskoleprogram, hvor pluralismen er noget større, er det tydeligt, at det markedsdrevne perspektiv er referencerammen. Grant (2005) refererer til en diskurs, hvor relationen mellem vejleder og ph.d.-studerende ses som et sælger-køber bytteforhold, men understreger samtidig, at diskursen endnu kun italesættes i den administrative, ledelsesmæssige retorik. Det aktuelle stykke empiri viser, at diskursen nu også findes i den akademiske retorik og praksis - og at den i øvrigt står stærkt. Vores pointe i denne sammenhæng er, at alle 3 perspektiver spiller en rolle i ph.d.-vejledningen. De rummer hver deres berettigelse, i en kompleks universitetsverden præget af forskellige hensyn og interesser - og bør som følge heraf alle 3 øve indflydelse. Hvis alene markedsperspektivet bestemmer over financieringen af de ph.d.-studerende eller driver forventninger om færdiggørelse og forskningsmæssige bidrag fra de ph.d.-studerende, så bliver det fx sværere at indfri universitetets internationaliseringsbestræbelser. Og på samme måde: De forskningsmiljøer, der ikke umiddelbart bidrager til lokal eller national vækst og velfærd, men som på anden vis holder den akademiske fane højt, vil også få det sværere.

Det er vigtigt at forstå perspektiverne som værende udtryk for abstrakte idealtyper, hvor den rent praktiske vejledning går på tværs af disse. I den ideelle vejledningssituation anvender vejlederen de positive sider fra hvert perspektiv. Det er ikke nok kun at opdrage næste generation af forskere til at anvende viden uden også at imødekomme høje akademiske standarder. Det er heller ikke nok kun at udvikle viden indenfor et traditionelt akademisk univers uden at have omtanke for kontekst, kultur og anvendelse. Universitetspædagogisk giver det god mening at konkludere, at vejledere med fordel kan stifte bekendtskab med og diskutere disse væsensforskellige perspektiver på vidensproduktion - så hver enkelt bliver opmærksom på forcer og faldgruber og kan tage stilling til, hvordan de skal håndteres. 
Pia Bøgelund er projektleder og ekstern lektor ved Institut for Planlægning på Aalborg Universitet. Hun arbejder med efteruddannelse og kompetenceudvikling af universitetsansatte og forsker i vejledningspraksis og gruppedynamik. Hun er p.t. tovholder i projektet Kompetenceløft af ph.d.-vejlederen $i$ en interkulturel virkelighed.

Anette Kolmos er professor og leder af UNESCO Chair in Problem Based Learning in Engineering Education, hoor der er indskrevet mange internationale ph.d.-studerende, der forsker i aspekter af problembaseret og projektorganiseret læring og ønsker at forandre deres uddannelser i hjemlandene.

\section{Litteratur}

Barnett, R. (1994). The Limits of Competence - Knowledge, Higher Education and Society. Buckingham: Open University Press.

Barnett, R. (2011). Being a University. London: Routledge

Bøgelund, P. (2011). Kompetenceløft af ph.d.-vejlederen i en interkulturel virkelighed - Forbedring af praksis og viden omkring supervision af udenlandske ph.d.-studerende. Projektbeskrivelse.

Bøgelund, P. \& Kolmos, A. (2013). Flere og mere internationale ph.d.-studerende Hvad betyder det for ph.d.-vejledningen? Indleveret til Dansk Universitetspædagogisk Tidsskrift. Odense: Syddansk Universitetsforlag.

Delamont, S., Atkinson, P. \& Parry, O. (2004). Supervising the Doctorate. A guide to success. ( $2^{\text {nd }}$ ed.). Maidenhead: The Society for Research into Higher Education and Open University Press.

Dunleavy, P. (2003). Authoring a PhD. How to Plan, Draft, Write and Finish a Doctoral Thesis or Dissertation. China: Palgrave study guides.

Dysthe, O. (2002). Professors as mediators of academic text cultures. An interview study with advisors and master degree students in three disciplines in a Norwegian university. Written Communication, 19(4), 493-544.

Eley, A. \& Jennings, R. (2005). Effective Postgraduate Supervision. Improving the Student/Supervisor Relationship. Maidenhead: Open University Press.

Forsknings- og Innovationsstyrelsen (2011). Evaluering af forskerkarriereveje- håndtering af forskeres karrierer på de danske universiteter. København: Forsknings- og Innovationsstyrelsen.

Grant, B. (2005). The pedagogy of graduate supervision: Figuring the relations between supervisor and student. Auckland: The university of Auckland, Aoteraroa.

Handal, G. \& Lauvås, P. (2006). Forskningsveilederen. Oslo: Cappelen Akademisk Forlag.

Jamison, A., Christensen, S. H. \& Botin, L. (2011). A hybrid imagination. Science and technology in cultural perspective. London: Morgan \& Claypool Publishers.

Lee, A. (2008). How are doctoral students supervised? Concepts of doctoral research supervision. Studies in Higher Education, 3/2008, 267-281

Rugg, G. \& Petre, M. (2004). The unwritten rules of PhD research. Maidenhead: Open University Press. 
Taylor, S. \& Beasley, N. (2005). A handbook for doctoral supervisors. New York: Routledge.

Wenneberg, S. B. (2001). Vidensledelse på universiteterne - når viden både skal produceres og anvendes. Ledelse og Erhvervsøkonomi, 1/2001, 39-48. 